\title{
Perbandingan Kurikulum 2013 Indonesia dengan Kurikulum Australia dengan Fokus pada Ilmu Pengetahuan Alam
}

\author{
Comparison of Indonesian Curriculum 2013 with The Australian Curriculum \\ Focusing on Science
}

\author{
Michael Michie \\ Batchelor Institute of Indigenous Tertiary Education, Darwin, Northern Territory, Australia \\ michael.michie@batchelor.edu.au
}

Naskah diterima tanggal 05/05/2019, direvisi akhir tanggal 27/05/2019, disetujui tanggal 31/07/2019

\begin{abstract}
Abstrak
Penerapan kurikulum baru untuk sekolah Indonesia diharapkan akan menghasilkan perubahan pada masyarakat Indonesia begitu juga pada pengetahuan para peserta didik. Kurikulum baru ini yang bernama Kurikulum 2013 mengacu kepada dua jenjang kompetensi-kompetensi Inti dan Kompetensi Dasar. Kompetensi Inti diterapkan untuk setiap kelas dan setiap mata pelajaran, serta meliputi kompetensi sikap spiritual, kompetensi sikap sosial, kompetensi pengetahuan, kompetensi keterampilan dan penerapan pengetahuan. Kurikulum Ilmu Pengetahuan Alam (IPA) untuk Sekolah Menengah Pertama (SMP) diperkenalkan sebagai integrative science, dan pendekatan antar-kurikulum ditujukan untuk beberapa kompetensi dasar dengan tingkat keberhasilan yang lebih tinggi dibanding kompetensi dasar lain. Pendekatan itu dianggap sebagai titik lemah para siswa sekolah di Indonesia terutama pada ujian berskala internasional seperti PISA dan TIMSS. Ketika disandingkan dengan Australian Curriculum, kurikulum IPA versi Australia memiliki beberapa persamaan dan perbedaan dengan muatan konten yang kurang lebih sama terutama dari segi gagasan pokok dan aspek keterampilan, namun perbedaannya terletak pada penilaian prestasi pada setiap jenjang kurikulum. Keberlanjutan adalah prioritas antar-kurikulum pada kedua kurikulum. Nampaknya sejak awal penerapan Kurikulum 2013 ini telah menuai kontroversi di Indonesia. Mendikbud yang baru mengizinkan sekolah menggunakan Kurikulum 2006 (KTSP) sebagai kurikulum lama selama Kurikulum 2013 diuji lebih lanjut.
\end{abstract}

Kata kunci: Kurikulum Indonesia 2013, Kurikulum Australia, Integrative Science, Kompetensi, Kurikulum Nasional.

\begin{abstract}
The introduction of a new curriculum in Indonesian (Kurikulum 2013) schools seeks to bring about changes in Indonesian society as well as students'knowledge base. The curriculum is based on two layers of competencies: Core Competencies, and Basic Competencies. Core Competencies are applicable at all year levels and for all subjects. They include religious and social attitudes as well as knowledge, skills, and the application of knowledge. The science(IPA) curriculum for junior high school is promoted as integrative science; some of the basic competencies demonstrate a cross-curriculum approach more successfully than others. When compared to the Australian Curriculum: Science, the IPA curriculum reveals that the contents are similar, as are key ideas and skills, and each curriculum has its approach to assessing achievement. Sustainability is a major cross-curriculum feature of both curriculums. The introduction of Kurikulum 2013 has not been without controversy. The new Minister of Education and Culture, however, allowed the schools to use the existing curriculum (Kurikulum 2006 or the so-called School-Based Curriculum) while the Kurikulum 2013 undergoes further trialling.
\end{abstract}

Keywords: Indonesian Curriculum 2013, Australian Curriculum, Integrative Science, Competencies, National Curriculum. 


\section{PENDAHULUAN}

Tulisan ini merupakan sebuah tinjauan ihwal Kurikulum 2013 sebagai kurikulum sekolah terbaru yang dikembangkan oleh Kementerian Pendidikan dan Kebudayaan Pemerintah Republik Indonesia. Penerapan Kurikulum 2013 ini nampaknya memang telah mengundang banyak kontroversi, dan tulisan ini akan mengemukakan beberapa isu penting mengenai kontroversi Kurikulum 2013 tersebut.

Bagian awal makalah ini berisi tentang pemaparan tentang perbandingan pendidikan sekolah dasar dan menengah di Indonesia dan di Australia. Sebagian Kurikulum 2013 akan diuji landasannya, serta kompetensi pada kurikulum. Perbandingan dengan Australian Curriculum akan dijelaskan di sini. Sesudah itu kurikulum untuk Ilmu Pengetahuan Alam (IPA) akan diuji, khususnya untuk tingkat pendidikan Sekolah Menengah Pertama (SMP), kemudian dibandingkan dengan situasi di Australia. Akhirnya kontroversi yang di sekitar penerapan Kurikulum 2013 ini dan beberapa isu penting ihwal kontroversi tersebut akan diuji.

1. Sistem pendidikan sekolah dasar dan menengah di Indonesia

Sekolah di Indonesia terdiri dari dua jenis yaitu sekolah negeri (umum) dan swasta. Sekolah umum adalah sekolah yang dikelola oleh dua kementrian yaitu Kementrian Pendidikan dan Kebudayaan (Kemendikbud) yang memayungi sebagian besar sekolah umum dari mulai tingkat sekolah dasar sampai dengan perguruan tinggi umum dan Kementrian Agama (Kemenag) yang membawahi madrasah-madrasah dan Pendidikan Tinggi Islam. Kurikulum untuk semua sekolah, baik sekolah di bawah kendali Kemendikbud maupun sekolah Kemenag, diatur oleh Kemendikbud.

Sistem pendidikan di Indonesia dibagi menjadi tiga tingkatan pendidikan sekolah formal, yaitu Sekolah Dasar (SD, Kelas I-VI), Sekolah Menengah Pertama (SMP, Kelas VII-IX) dan Sekolah Menengah Atas (SMA, Kelas X-XII). Di tingkat ketiga juga ada Sekolah Menengah Kejuruan (SMK, Kelas $\mathrm{X}$-XII) yang mempunyai fokus di berbagai bentuk pendidikan kejuruan. Di Indonesia pendidikan sekolah diwajibkan pemerintah untuk semua murid dari Kelas I sampai Kelas IX, walaupun masih ada yang tidak bisa bersekolah akibat orangtuanya tidak mampu. Menurut Suharti (2012), sekitar 81\% murid menyelesaikan SD pada tahun ajaran 2007/08, dan 87\% murid yang mulai SMP pada tahun ajaran 2004/05 menyelesaikan tiga tahun yang berikutnya. Pada tahun 2013, Kemendikbud mengumumkan program wajib belajar dua belas tahun, yaitu dari Kelas I SD sampai Kelas XII SMA (Natahadibrata, 2013).

2. Sistem pendidikan sekolah di Australia Negara Australia adalah persemakmuran federal yang terdiri dari enam negara bagian dan dua teritori. Keenam negara bagian tersebut meliputi New South Wales, Victoria, Queensland, Tasmania, South Australia and Western Australia, dan dua teritori yang meliputi Australian Capital Territory and Northern Territory. Setiap negara bagian dan teritori tersebut bertangungjawab untuk menyelenggarakan pendidikan sekolah dalam batas wilayahnya masing-masing. Setiap pemerintah negara bagian dan teritori mempunyai departemen atau kementerian pendidikan tersendiri, dan juga pemerintah persemakmuran mempunyai departemen pendidikan tersendiri. Beberapa fungsi negara bagian dan teritori dapat diserahkan kepada pemerintah persemakmuran ketika hal tersebut telah mendapatkan pengakuan hukum di wilayah pemerintahannya masing-masing. Australian Curriculum adalah semacam contoh persetujuan ini.

Sekolah-sekolah di Australia terdiri dari tiga jenis yaitu sekolah umum (atau sekolah pemerintah negara bagian atau teritori), sekolah Katolik dan sekolah mandiri. Sekolah umum adalah sekolah yang didirikan oleh pemerintah negara bagian dan teritori masing-masing, sedangkan sekolah Katolik dan mandiri dibentuk oleh organisasi keagamaan dan organisasi kemasyarakatan. Meskipun menyandang status yang berbeda, setiap sekolah di Australia, apapun jenisnya, berhak menerima anggaran pendidikan baik 
dari pemerintah persemakmuran maupun negara bagian atau teritori masing-masing.

Sebagian besar sekolah menggunakan kurikulum yang disusun oleh pemerintah, baik itu dari pemerintah persemakmuran maupun negara bagian dan teritori, tetapi beberapa sekolah menggunakan kurikulum internasional (misalnya International Baccalaureate) atau kurikulum khusus.

Sistem pendidikan di Australia terbagi menjadi tiga tingkat pendidikan sekolah formal, yaitu primary (sekolah dasar atau Years [tahun atau kelas] 1-6 atau 1-7); junior secondary atau middle school (sekolah menengah pertama, Years 7-10 atau 7-9 atau 8-10); dan senior secondary (sekolah menengah atas, Years 11-12 atau 10-12). Perlu diperhatikan bahwa durasi pendidikan sekolah dasar di Australia bisa berbeda-beda di tiap negara bagian dan teritori. Tabel 1 berikut menyuguhkan informasi dasar perihal durasi pendidikan sekolah dasar di Australia. Perlu diketahui juga bahwa kehadiran di sekolah diwajibkan untuk siswa dari umur lima tahun sampai umur 17 tahun. Menurut data statistik terbaru (ACARA, 2016b), $82,5 \%$ siswa dari Year 10 menyelesaikan Year 12.

Tabel 1. Informasi dasar perihal durasi pendidikan sekolah di negara bagian atau teritori di Australia (ACARA, 2016b)

\begin{tabular}{|c|c|c|c|}
\hline \multirow[b]{2}{*}{ Negara bagian atau teritori } & \multicolumn{3}{|c|}{ Tinggi Penyekolahan (year = kelas) } \\
\hline & Primary (SD) & Junior high / middle & Senior high school \\
\hline $\begin{array}{l}\text { New South Wales, Victoria, } \\
\text { Tasmania, Australian } \\
\text { Territory }\end{array}$ & Years 1-6 & Years 7-10 & Years 11-12 \\
\hline Northern Territory & Years 1-6 & Years 7-9 & Years 10-12 \\
\hline $\begin{array}{l}\text { Queensland, South Australia, } \\
\text { Western Australia }\end{array}$ & Years 1-7 & Years 8-10 & Years 11-12 \\
\hline
\end{tabular}

\section{KURIKULUM 2013}

Kurikulum $2013 \quad$ (Kementerian Pendidikan dan Kebudayaan [Kemendikbud], 2012) diluncurkan selama masa jabatan kedua (2009-2014) Presiden Susilo Bambang Yudhoyono oleh Menteri Pendidikannya (Mendikbud), yaitu Mohammad Nuh pada tahun 2012'. Dokumen Kurikulum 2013 adalah sebutan untuk dokumen utama kurikulum yang baru dilaksanakan oleh Kemendikbud pada Desember 2012. Kurikulum itu diperkenalkan di semua sekolah di Indonesia mulai Juli 2013 di jenjang tertentu. Pada tahun 2013, tiga dokumen diumumkan oleh Kemendikbud dan disebut Kompetensi Dasar untuk jenjang pendidikan masing-masing (Kemendikbud, 2013a; b; c); dokumen ketiga juga digunakan untuk Sekolah Menengah Kejuruan (SMK). Kurikulum 2013 mengganti kurikulum sebelumnya, yaitu Kurikulum Tingkat Satuan Pendidikan (KTSP) atau Kurikulum 2006.
Kurikulum 2013 mempunyai latar belakang, landasan, dan prinsip tersendiri untuk basis pengembangannya, strukturnya, dan impelementasinya. Informasi latar belakangnya meliputi landasan yuridis, filosofis, teoritis dan empiris (Kemendikbud, 2012).

1. Landasan yuridis

Menurut Undang-Undang Dasar 1945 dan Pancasila, Pemerintah Republik Indonesia bertanggung jawab untuk pembangunan pendidikan terhad untuk pengembangan pendidikan yang sesuai dengan kebutuhan masyarakat. Juga Undang-Undang (UU) nomor 20 tahun 2003 tentang Sistem Pendidikan Nasional adalah perundang-undangan penting. Di undang-undang ini, Pemerintah RI mempunyai kewajiban tanggung jawab untuk kebijakan pendidikan, kurikulum dan standar pendidikan nasional (Al-Samarrai \& CerdanInfantes, 2012). Kemendikbud adalah bagian dari Pemerintah RI yang bertanggung jawab untuk menyusun pendidikan dasar dan menengah,

\footnotetext{
${ }^{1}$ Pada tahun 2014, Joko Widodo dipilih presiden yang baru, dan Anies Baswedan ditunjuk Mendikbud yang baru.
} 
dan menyiapkan dokumen kurikulum untuk digunakan di sekolah di seluruh Indonesia.

2. Landasan filosofis

Hubungan antara pendidikan, kebudayaan, dan agama terjalin erat sekali di dokumen-dokumen kurikulum Indonesia ini. Fungsi pendidikan membangun semua peserta didik $^{2}$ menjadi warga negara yang baik. Menurut UU RI nomor 20 tahun 2003, peserta didik "menjadi manusia yang beriman dan bertaqwa kepada Tuhan Yang Maha Esa, berakhlak mulia, sehat, berilmu, cakap, kreatif, mandiri, dan menjadi warganegara yang demokratis serta bertanggungjawab" (Kemendikbud, 2012: 3). Pernyataan ini diulangi pada dokumen kurikulum lain berikut komentarnya. Hubungan ini juga dua arah; "pendidikan berakar pada budaya bangsa" (Kemendikbud, 2012: 3).

3. Landasan teoritis

Kurikulum 2013 didasarkan pada dua nosi pendidikan, yaitu kompetensi dan standar pendidikan. Sebelum dokumendokumen Kurikulum 2013 ditulis, sudah ada dokumen Standar Kompetensi Lulusan (SKL) dan Standar Isi (SI), yang disebutkan di dalam kurikulum itu. Dokumen standar ini dikembangkan oleh Badan Standar Nasional Pendidikan (BSNP) untuk Kemendikbud.

Menurut Kemendikbud (2012: 5), "Kompetensi adalah kemampuan seseorang untuk bersikap, menggunakan pengetahuan dan keterampilan untuk melaksanakan suatu tugas di sekolah, masyarakat dan lingkungan di mana yang bersangkutan berinteraksi." Kurikulum 2013 adalah merupakan rencana untuk peserta didik agar mengalami kesempatan pembelajaran luas dalam bersikap, berpengetahuan dan berketerampilan untuk meningkatkan kemampuannya.

Pada Kurikulum 2013 ada dua jenis kompetensi, yaitu Kompetensi Inti dan Kompetensi Dasar. Kompetensi Inti adalah kompetensi penting yang digunakan di seluruh dokumen kurikulum, dan ada empat kompetensi yang digambarkan yaitu kompetensi sikap spiritual, kompetensi sikap sosial, kompetensi pengetahuan dan kompetensi keterampilan
(Nuh, 2013). Teks Kompetensi Inti hampir sama untuk semua tingkat dan semua mata pelajaran. Kompetensi Dasar berbeda dan berkembang pada setiap tingkat, dan antara mata pelajaran. Kompetensi Dasar meliputi semua pengetahuan dan keterampilan yang harus diajar pada setiap mata pelajaran untuk tingkat masing-masing. Semua Kompetensi Inti dan Kompetensi Dasar digambarkan untuk mata pelajaran dan tingkat masing-masing (Kemendikbud, 2013a; b; c).

Kurikulum 2013 bukan kurikulum Indonesia pertama yang menggunakan kompetensi berbasis kurikulum; kompetensi juga digunakan pada Kurikulum Berbasis Kompetensi (KBK atau Kurikulum 2004) dan Kurikulum Tingkat Satuan Pendidikan (KTSP atau Kurikulum 2006).

Standar Kompetensi Lulusan adalah kualitas minimal untuk peserta didik ketika mereka akan lulus dari SD, SMP atau SMA/SMK. Standar Kompetensi Lulusan mencakup sikap, pengetahuan, dan keterampilan (Kemendikbud, 2012). Satuan masing-masing berisikan tiga komponen, yaitu kemampuan minimal proses, konten dan ruang lingkup dalam penggunaan komponen proses dan konten. Standar Isi adalah lingkup materi minimal untuk mencapai Standar Kompetensi Lulusan. Ini juga diatur pada mata pelajaran dan jenjang sekolah.

4. Landasan empiris

Faktor lain yang tidak mempunyai hubungan dilukiskan sebagai landasan empiris. Menurut dokumen yang ada (Kemendikbud, 2012), ekonomi Indonesia terus tumbuh dan peserta didik memerlukan gemblengan menjadi wirausahawan yang baru. Peserta didik seharusnya menjadi warga negara Indonesia yang terintegrasi. Mereka seharusnya belajar menyelesaikan perselisihan dengen aspek kognitif, tidak dengan kekerasan. Fokus diperlukan pada tingkat sekolah dasar kepada peningkatan tiga kemampuan dasar, yaitu baca, tulis, dan hitung serta pembentukan karakter. Hasil studi PISA dan TIMSS $^{3}$ menunjukkan perlu untuk peserta didik memfokuskan tidak hanya

\footnotetext{
${ }^{2}$ Peserta didik adalah peristilahan digunakan seluruh dokumen kurikulum daripada murid atau siswa.

${ }^{3}$ PISA = Program for International Student Assessment, TIMSS = Trends in International Mathematics and Science Study. Peserta didik Indonesia sudah melakukan pada acara ini dengan hasil rendah (Suharti, 2013).
} 
konten tetapi juga kemampuan esensial lain. Peserta didik juga perlu mengetahui tantangan lingkungan Indonesia, misalnya pencemaran, kurangnya sumber air bersih, potensi rawan pangan, dan pemanasan global.

\section{STRUKTUR KURIKULUM 2013}

Kurikulum dipisah dalam tiga jenjang yaitu Sekolah Dasar (Kelas I-VI), Sekolah Menengah Pertama (Kelas VIIIX) dan Sekolah Menengah Atas (Kelas X-XII). Struktur jenjang itu serupa. Struktur digambarkan pada Dokumen Kurikulum 2013 dan juga Kompetensi Dasar untuk jenjang masing-masing.

Pada SD dan SMP, mata pelajaran adalah dikelompokkanmenjadi dua dan semua mata pelajaran bersifat wajib, serta mata pelajaran untuk SD dan SMP diperlihatkan sebagai berikut pada Tabel 2; (Kemendikbud, 2012). Selain itu, aktivitas ekstra-kurikuler dianjurkan, misalnya Pramuka (yang diwajibkan untuk SMP), Organisasi Siswa Intrasekolah, Unit Kesehatan Sekolah dan Palang Merah Remaja.

Menurut kurikulum untuk Sekolah Dasar, Ilmu Pengetahuan Alam (IPA) dan Ilmu Pengetahuan Sosial (IPS) tidak diajarkan seperti mata pelajaran terpisah: kontennya "diintegrasikan ke dalam mata pelajaran PPKn, Bahasa Indonesia dan Matematika yang harus ada berdasarkan ketentuan perundangundangan" (Kemendikbud, 2012: 14). Karena ini, pendekatan tematik dianjurkan ketika kompetensi untuk dua mata pelajaran serupa.
Contoh-contoh tema berjenis-jenis terdapat pada lampiran Kemendikbud SD (2013a).

Deskripsi kurikulum Indonesia untuk SMP dapat ditemukan pada Kompetensi Dasar SMP (Kemendikbud SMP, 2013b). Dokumen ini meliputi struktur kurikulum dan beban belajar, serta organisasi kompetensi dasar untuk setiap mata pelajaran masing-masing. Di sini terdapat Kompetensi Inti SMP dengan Kompetensi Dasar mata pelajaran IPA.

Pada SMA, mata pelajaran dipisah dalam dua kelompok yang berbeda, yaitu kelompok wajib dan kolompok peminatan (Kemendikbud SMA, 2013c). Banyak mata pelajaran dari SMP tetap wajib (tidak bagi IPA atau IPS) dan peserta didik bisa memilih mata pelajaran peminatan (misalnya Peminatan Matematika dan Sains meliputi Matematika, Biologi, Fisika, dan Kimia).

Kurikulum juga meliputi alokasi waktu belajar per minggu untuk peserta didik untuk semua tingkat, dan lamanya satu jam belajar.

\section{AUSTRALIAN CURRICULUM (KURIKULUM AUSTRALIA)}

Di Australia ada tiga jenjang pemerintah, yaitu pemerintah persemakmuran atau nasional; enam pemerintah negara bagian dan dua pemerintah wilayah; dan banyak pemerintah lokal. Tanggung jawab untuk pendidikan sekolah dasar dan menengah dimiliki oleh pemerintah negara bagian atau pemerintah wilayah, dan meliputi persiapan kurikulum.

Tabel 2. Mata pelajaran untuk SD dan SMP menurut Kemendikbud (2012)

\begin{tabular}{lll}
\hline & \multicolumn{1}{c}{ Sekolah Dasar } & \multicolumn{1}{c}{ Sekolah Menengah Pertama } \\
\hline $\begin{array}{l}\text { Kelompok A: mata pelajaran yang } \\
\text { berorientasi lebih kepada aspek }\end{array}$ & 1. Pendidikan Agama & 1. Pendidikan Agama \\
intelektual dan afektif & 2. Pendidikan Pancasila dan & 2. Pendidikan Pancasila dan \\
& Kewarganegaraan (PPKn) & \multicolumn{1}{c}{ Kewarganegaraan } \\
& 3. Bahasa Indonesia & 3. Bahasa Indonesia \\
& 4. Matematika & 4. Matematika \\
& 5. Ilmu Pengetahuan Alam & 5. Ilmu Pengetahuan Alam \\
& 6. Ilmu Pengetahuan Sosial & 6. Ilmu Pengetahuan Sosial \\
& & 7. Bahasa Inggris \\
\hline $\begin{array}{l}\text { Kelompok B: mata pelajaran yang } \\
\text { berorientasi lebih kepada aspek } \\
\text { afektif dan psikomotor (termasuk }\end{array}$ & 1. Seni Budaya dan & 1. Seni Budaya \\
muatan lokal) & 2. Pendidikan Jasmani, Olah & 2. Pendidikan Jasmani, Olah \\
& Raga dan Kesehatan & Raga dan Kesehatan
\end{tabular}


Meskipun kurikulum sekolah nasional disetujui oleh semua pemerintah negara bagian dan pemerintah wilayah pada tahun 2008, Australian Curriculum, Assessment and Reporting Authority (ACARA; Otoritas Australia untuk Kurikulum, Penilaian dan Laporan) diciptakan Parlemen Australia dengen Undang-Undang ACARA tahun 2008 (ACARA, 2012). Salah satu fungsi ACARA adalah memiliki kurikulum sekolah nasional dengan konten dan standar prestasi (Australian Curriculum). ACARA juga bekerja dengan petunjuk strategis yang diidentifikasi pada Melbourne Declaration (MCEETYA, 2008).

Secara filosofis, "Australian Curriculum dirancanguntukmengembangkan pelajar sukses, pribadi yang percaya diri dan kreatif, serta warganegara yang aktif dan berpengetahuan" (ACARA, 2016a). Landasan filosofis Australian Curriculum dinyatakan pada cita-cita Melbourne Declaration (MCEETYA, 2008).

Menurut ACARA (2016a), struktur Australian Curriculum berlaku sama untuk delapan learning areas atau mata pelajaran, yaitu Bahasa Inggris, Matematika, IPA, Pendidikan Kesehatan dan Jasmani, Ilmu Sastera, Seni Budaya, Teknologi dan Bahasa Asing. Struktur dokumennya pun sama untuk Fondasi ${ }^{4}$ sampai Kelas X (SD sampai SMP); struktur kurikulum berbeda untuk Kelas XI dan XII (SMA). Sekolah Katolik dan sekolah mandiri lain bahwa didirikan prinsip agamanya boleh meliputi pelajaran agama dan ibadahnya pada acara sekolah. Kurikulum Fondasi-Kelas X dikembangkan dalam ranah pengetahuan, keterampilan dan pemahaman mata pelajaran; kemampuan umum; dan prioritas antar-kurikulum.

1. Kemampuan umum adalah kelompok yang integrasi dan antar-koneksi pengetahuan, keterampilan, kelakuan dan watak yang dipergunakan antar semua mata pelajaran, yaitu Literasi; Numerasi; Kemampuan dengan teknologi informasi dan komunikasi; Kemampuan berfikir kritis dan kreatif, Kemampuan pribadi dan sosial; Pemahaman etis; dan Pemahaman antar-kebudayaan.

2. Ada tiga prioritas antar-kurikulum yang akan dikembangkan melalui mata pelajaran, yang relevan: yaitu Sejarah dan kebudayaan orang asli Australia; Asia dan keterlibatan Australia dengan Asia; dan Keberlanjutan.

Menurut ACARA (2016a), standar prestasi (achievement standards) dan deskripsi konten adalah elemen penting learning areas atau mata pelajaran di dalam kurikulum.

1. Standar prestasi untuk setiap mata pelajaran menggambarkan pembelajaran oleh peserta didik untuk jenjang kelas masing-masing. Fokus standar prestasi adalah untuk pengembangan program belajar-mengajar oleh guru. Guru dapat mengawasi pembelajaran peserta didik serta menilai kemajuan dan prestasi peserta didik dengan penggunaan contoh pekerjaan.

2. Deskripsi konten menggambarkan konten yang diajarkan oleh guru dan dipelajari oleh peserta didik. Deskripsi konten meliputi pengetahuan, pemahaman dan keterampilan untuk jenjang kelas masingmasing. Ada juga elaborasi konten pilihan untuk guru memutuskan konten yang akan dipakai untuk mengajar.

Konsistensi struktural pada dokumen kurikulum dicapai dengan menggunakan mata pelajaran yang dibagi menjadi ide yang serupa dengan subbagian dipanggil strands dan sub-strands. Struktur ini akan diuji pada konteks kurikulum IPA berikut ini.

\section{PERBANDINGAN KURIKULUM 2013 INDONESIA DENGAN AUSTRALIAN CURRICULUM}

Kurikulum 2013 Indonesia dan Australian Curriculum adalah dua kurikulum yang modern tetapi mempunyai dua pendekatan berbeda. Dokumen Kurikulum 2013 ditulis dengan banyak rincian, termasuk landasan dan prinsip pengembangan yang didasarkan pada teori pendidikan. Australian

\footnotetext{
$\overline{{ }^{4} \text { Fondasi menggunakan pada }}$ dokumen Australia Curriculum sama nama tahun pertama sekolah di Australia karena tahun ini mempunyai nama berbeda antar negara bagian dan wilayah.
} 
Curriculum tidak mempunyai rincian sebanyak Kurikulum 2013.

Perbedaan penting pada Kurikulum 2013 adalah pengunaan kompetensi, khususnya Kompetensi Inti. Ada empat kompetensi yang dapat diringkas sebagai kompetensi sikap spiritual, kompetensi sikap sosial, kompetensi pengetahuan dan kompetensi keterampilan (Nuh, 2013) ${ }^{5}$.

1. Kompetensi Inti pertama merujuk pada ajaran agama yang dianut peserta didik Indonesia, tetapi tidak ada untuk peserta didik Australia.

2. Kompetensi Inti kedua adalah kompetensi sikap sosial dan menunjukkan sikap kebudayaan Indonesia, misalnya gotong royong, terutama antara masyarakat dan keberadaan peserta didik. Pada Australian Curriculum ada kemampuan umum Disebutkan mengenai kemampuan umum yang difokuskan lebih utama pada masing-masing pribadi siswa, bukan pada masyarakat.

3. Kompetensi Inti ketiga dan Kompetensi Inti keempat adalah tentang pengetahuan dan keterampilan untuk setiap mata pelajaran. Terdapat fungsi yang sama untuk deskripsi konten pada Australian Curriculum, tetapi tidak ditulis sebagai kompetensi.

Dokumen penunjang Kurikulum 2013 yang kemudian dilahirkan adalah Kompetensi Dasar untuk SD, SMP dan SMA (Kemendikbud, 2013a; b; c). Pada dokumen-dokumen ini termuat Kompetensi Dasar untuk setiap mata pelajaran dan kelas masing-masing. Konten setiap mata pelajaran diuraikan sebagai kompetensi-kompetensi yang harus dicapai oleh peserta didik. Pada kurikulum Australia juga ada dokumen lain untuk setiap mata pelajaran FondasiKelas X, misalnya Australian Curriculum: Science (ACS; ACARA, 2015). Konten kurikulum ditulis sebagai penggambaran konten (content descriptions) dan penjelasan (elaborations), tidak sebagai kompetensi atau hasil (outcomes). Struktur ACS akan digambarkan di bawah ini.
Standar Kompetensi Lulusan pada Kurikulum 2013 adalah kualitas minimal peserta didik ketika mereka akan lulus dari SD, SMP atau SMA. Pada Australian Curriculum ada standar prestasi untuk setiap mata pelajaran yang menggambarkan pembelajaran oleh peserta didik untuk setiap jenjang kelas. Standar prestasi tidak digunakan untuk menetapkan kalau peserta didik lulus dari SD atau SMP di Australia.

Kurikulum 2013 tidak mempunyai aspek yang mirip dengan prioritas antarkurikulum yang akan dikembangkan melalui mata pelajaran. Keberlanjutan dimasukkan pada kurikulum IPA, walaupun kurikulum ini menganjurkan bahwa "pengembangan sikap peduli dan bertanggung jawab terhadap lingkungan sosial dan alam" untuk IPA dan IPS (Kemendikbud SMP, 2013b: 2). Tema ini ditunjukkan oleh Prihantoro (2015) seperti pendidikan lingkungan yang diajarkan di lintas kurikulum pada setiap mata pelajaran tetapi khususnya pada IPA dan IPS.

Pada Kurikulum 2013 untuk SMA, struktur mata pelajaran mirip dengan struktur mata pelajaran SD dan SMP. Dalam Australian Curriculum terdapat lebih banyak mata pelajaran, misalnya untuk daerah IPA ada empat mata pelajaran: Biologi, Fisika, Kimia, serta Ilmu Bumi dan lingkungan. Kurikulum untuk semua mata pelajaran SMA belum ditulis oleh ACARA untuk Australian Curriculum.

\section{KURIKULUM 2013 DAN ILMU PENGETAHUAN ALAM (IPA)}

Kurikulum 2013 menganjurkan tiga pendekatan mengajar IPA untuk setiap jenjang pendidikan sekolah. Untuk SD, IPA akan diajar sebagai mata pelajaran yang terintegrasi dengan Pendidikan Pancasila dan Kewarganegaraan, Bahasa Indonesia dan Matematika. Untuk SMP, IPA "dikembangkan sebagai mata pelajaran integrative science .... bukan sebagai pendidikan disiplin ilmu" (Kemendikbud SMP, 2013b: 2). Untuk SMA, ada tiga mata pelajaran peminatan, yaitu Biologi, Fisika dan Kimia.

\footnotetext{
5 Pada Kemendikbud SMP (2013b: 5), Kompetensi Ilmu 4 diserahkan sebagai "penerapan pengetahuan" atau daftar kemampuan pada dokumen itu adalah benar-benar keterampilan proses.
} 
1. Ilmu Pengetahuan Alam (IPA) untuk Sekolah Menengah Pertama (SMP): Mengapa integrative science?

Tidak banyak referensi tentang integrative science pada dokumen Kompetensi Dasar SMP (Kemendikbud SMP, 2013b) dan tidak banyak Kompetensi Dasar yang menggambarkan metode tersebut. Pada contoh berikut ini, konten meliputi pengetahuan listrik dari disiplin Fisika dan juga pengetahuan badan manusia dan hewan dari disiplin Biologi. Ada contoh IPA yang digabungkan [integrated science].

Mengenal konsep listrik statis, potensial listrik, hantaran listrik, kelistrikan pada sistem syaraf, kelistrikan pada jantung, kelistrikan tulang, dan hewan-hewan yang mengandung listrik (Kelas VIII, Kemendikbud SMP, 2013b: 52)

Penggunaan istilah integrative science pada dokumen ini, khususnya ketika ditulis pada Bahasa Inggris, ketimbang integrated science, nampak tidak biasa atau agak janggal. Hal ini disebabkan karena istilah ini tidak pernah digunakan atau pernah digunakan dengan frekuensi kecil saja bahkan dalam kurikulum pendidikan Barat pada umumnya dan juga tidak pernah digunakan pada konteks pendidikan Australia pada khususnya. Integrative science sebenarnya sudah digunakan pada konteks perguruan tinggi (misalnya Barrett, 2001; Institute for Integrative Science and Health, 2017). Pada situasi ini, konsep sains terpadu dengan konsep sosial. Pengunaan integrative science pada sekolah menengah sangat terbatas, menurut referensi. Namun, IPA pada Kurikulum 2013 meliputi baik kompetensi ajaran agama dan kompetensi sikap sosial, dan sikap kebudayaan Indonesia, maupun kompetensi tentang pengetahuan dan keterampilan IPA. Dengan demikian, maka barangkali IPA barulah bisa dianggap sama atau sejajar dengan istilah integrative science.

Untuk setiap kelas IPA SMP terdapat buku panduan guru yang diterbitkan oleh Kemendikbud. Setiap buku guru (misalnya Kemendikbud, 2014) mempunyai dua bagian. Bagian pertama berisi tentang pengajaran, pembelajaran, dan penilaian IPA; sedangkan bagian kedua berisi ihwal strategi pembelajaran IPA untuk kelas tersebut dan dilengkapi dengan penggunaan buku siswa. Penilaian untuk Kompetensi Inti 1 dan 2 diliputi juga pada bagian pertama.

2. Struktur Australian Curriculum: Science (ACS) dan perbandingan dengan Kurikulum 2013 IPA

Pada ACS terdapat beberapa ciri yang tidak ditemukan pada Kurikulum 2013. Pertama, ada peninjauan luas meliputi pemikiran, tujuan dan ide pokok (key ideas). Menurut ACARA (2015), ada enam ide pokok di dalam $A C S$ : Pola, urutan dan organisasi; Kondisi dan fungsi; Stabilitas dan perubahan; Skala dan ukuran; Zat dan energi; serta Sistem-sistem. Menurut Kemendikbud (2014), ada empat tema lebih besar yang mengarah pada pemaduan, yaitu materi, sistem, perubahan dan interaksi, dua daftar ini serupa.

ACS mempunyai tiga bagian antarhubungan atau strands, yaitu Science understandings (Pengertian ilmu), Science as a human endeavour (Ilmu sebagai usaha manusia), dan Science inquiry skills (Keterampilan penyelidikan ilmu). Science understandings dibagi menurut disiplin atau sub-strands, yaitu Ilmu biologi, Ilmu kimia, Ilmu fisika dan Ilmu bumi dan angkasa. Meskipun demikian $A C S$ menganjurkan bahwa tiga bagian ini seharusnya diajar dengan metode integrasi, serupa untuk IPA SMP. Science understandings seperti Kompetensi Inti 3 di dalam Kurikulum 2013, tentang pengetahuan, dan Science inquiry skills seperti Kompetensi Inti 4, tentang keterampilan. Berikutnya, ada deskripsi pada dokumen untuk setiap kelas dari Fondasi sampai Kelas X tentang konten yang diajarkan, penggambaran konten dan penjelasan, dan standar prestasi untuk kelas itu.

Topik yang diajarkan pada kelas SMP dapat dibandingkan memakai informasi didirikan pada Kemendikbud SMP (2013b) dan ACARA (2015). Topik ini hanya menggambarkan konten dan tidak meliputi keterampilan atau penerapan pengetahuan. Banyak topik yang sama pada kurikulum 
SMP Indonesia dan Australia, walaupun judul topik tidak memiliki kesamaan. Ada lebih banyak penekanan pada Ilmu bumi dan angkasa pada $A C S$ daripada Kurikulum 2013. Terdapat lebih banyak penekanan pada sistem badan manusia pada Kurikulum 2013 daripada $A C S$. Biarpun beberapa topik dari Kurikulum 2013 belum ditemukan pada buku teks siswa.

\section{KURIKULUM 2013: SUATU KONTROVERSI SEJARAH}

Kurikulum 2013 diluncurkan selama masa jabatan kedua Presiden Susilo Bambang Yudhoyono oleh Mendikbud Mohammad Nuh, dengan dorongan Wakil Presiden Boediono, pada Desember 2012. Pada Oktober 2014, Joko Widodo dipilih menjadi presiden yang baru, dan dia menunjuk Anies Baswedan sebagai Mendikbud yang baru. Pada Desember 2014, Mendikbud Baswedan memerintahkan bahwa:

Satuan pendidikan dasar dan pendidikan menengah yang melaksanakan Kurikulum 2013 sejak semester pertama tahun pelajaran 2014/2015 kembali melaksanakan Kurikulum Tahun 2006 mulai semester kedua tahun pelajaran 2014/2015 sampai ada ketetapan dari Kementerian untuk melaksanakan Kurikulum 2013. (Pasal 1, Peraturan Menteri Pendidikan Dan Kebudayaan Republik Indonesia, Nomor 160 Tahun 2014)

Menurut peraturan ini juga, satuan pendidikan dasar dan pendidikan menengah yang telah melaksanakan Kurikulum 2013 selama 3 (tiga) semester tetap menggunakan Kurikulum 2013. (Pasal 2, Peraturan Menteri Pendidikan Dan Kebudayaan Republik Indonesia, Nomor 160 Tahun 2014).

Menurut Baswedan, alasan utama untuk perubahan kebijakan adalah karena kekurangan keadaan siap-sedia sekolah dan guru, juga tidak ada kesesuaian antar tujuan kurikulum dengan buku pelajaran sekolah (Budiari, 2014). Basweden juga berkata bahwa 6.221 sekolah dapat meneruskan Kurikulum 2013 dan merupakan sekolah rintisan penerapan kurikulum itu. "Mereka akan jadi contoh bagi sekolah yang belum siap," tambah Baswedan ("Mulai semester genap", 2014). Lebih dari 200.000 sekolah akan melaksanakan Kurikulum 2006.

Selama wawancara untuk Tempo (“Anies Baswedan”, 2014, h.156), beberapa komentar diberikan oleh Baswedan tentang penerapan Kurikulum 2013. "Secara prinsip, kurikulum memang harus mengalami perubahan." Juga menurut Baswedan, "Kurikulumnya baik, kok. Masalah utamanya adalah implementasi yang terburu-buru." Dia menganggap bahwa implementasi kurikulum seharusnya terjadi selama tujuh tahun. Menurut Peraturan Menteri Nomor 160 Tahun 2014, sekolah "dapat melaksanakan Kurikulum Tahun 2006 paling lama sampai dengan tahun pelajaran 2019/2020" (Pasal 4). Pada Ramli (2014), orang yang diwawancarai ("Professor John", yang badan penasehat Kurikulum 2013) berkata "pemerintah percaya bahwa kurikulum seharusnya direvisi atau diubah dalam waktu 5 atau 10 tahun" (Ramli, 2014: 82), serta "menurut saya kalau Menteri yang baru bisa mengintrodusir kurikulum baru dia seharusnya menyiapkannya dalam waktu 3-4 tahun" (Ramli, 2014: 83).

Kemampuan guru mengajar menurut pedagogi yang baru Kurikulum 2013 sudah diragukan. Menteri Baswedan berkata:

Jadi, yang harus dilatih untuk melaksanakan kurikulum itu bukan hanya gurunya, melainkan ekosistem sekolahnya....Ada sejumlah sekolah yang kami persiapkan sebagai percontohan. Lalu guru-guru dari sekolah lain dibawa dan mengajar di sana dalam kurun tertentu. Dia melihat langsung bagaimana kurikulumnya diterapkan dengan baik. ... Sekolah itu [6.221 sekolah disebut] akan menjadi sekolah percontohan - sebagai tempat pelatihan guru nantinya. ("Anies Baswedan", 2014: 158)

Jadi Mendikbud mempunyai rencana memperbaiki keterampilan guru-guru. Kualifikasi guru masih diperbaiki, walaupun tidak sama dengan di sekolah dasar atau semua daerah di Indonesia (Suharti, 2013). Bjork (2013) mempertimbangkan bahwa banyak guru Indonesia menganggap mereka sendiri sebagai pegawai pemerintah, bukan pendidik. Ramli (2014) menganggap juga bahwa 
kwalitas guru dan persiapan guru adalah pembatasan lain yang seharusnya dipusatkan oleh pemerintah. Perkembangan profesional (inservice) belum diselenggarakan untuk guru di Indonesia, khususnya di daerah miskin atau terpencil. Pada Januari 2016, Baswedan berkata bahwa pemerintah telah membekali 2,9 juta guru melalui uji kompetensi untuk sekolah pengguna tahun ini (Nugroho, 2016). Sekarang tentang 25\% jumlah sekolah bisa menerapkan Kurikulum 2013 mulai tahun 2016.

Masalah lain yang penting adalah buku pelajaran, yang tidak memiliki kesesuaian antar tujuan kurikulum dengan buku pelajaran. Di Indonesia, Kemendikbud bertanggung jawab dalam persiapan buku pelajaran yang baru untuk Kurikulum 2013. Banyak buku pelajaran yang baru dicetak sebelum Mendikbud menghentikan penggunaan kurikulum pada tahun 2014.

Revisi buku ... dilakukan berdasarkan perbaikan dari para ahli dan masyarakat yang tuntas pada akhir Oktober 2015. ... Dia menyebut, pihaknya melakukan revisi sebanyak 377 buku dan dipastikan bisa selesai pada Februari 2016. Harapannya, buku-buku tersebut dapat digunakan tahun ajaran 2016/2017. ("Kemdikbud", 2016)

Beberapa buku direvisi lebih banyak, khususnya perubahan pada tema untuk sekolah dasar kelas satu sampai enam.

Alasan lain diberikan untuk mengabaikan Kurikulum 2013, termasuk:

1. Terlalu banyak pekerjaan untuk peserta didik

2. Kurang cukup sumber pendidikan untuk banyak sekolah, khususnya itu di daerah miskin atau terpencil. Banyak sekolah Indonesia belum mempunyai koneksi online ke Internet, bahkan banyak sekolah belum mempunyai koneksi listrik.

3. Filsafat kurikulum serupa dengan agama Islam, khususnya tentang Kompetensi Inti 1.

A. Kurikulum IPA

Menurut Ramli (2014) ada beberapa masalah tentang konten dan pedagogi IPA di dalam sekolah dasar dan sekolah menengah pertama.
1). Di SD, dalam Kelas I-III tidak ada konten IPA (dan IPS) pada Kurikulum 2013, dan dalam Kelas IV-VI guru-guru diharapkan mengajar IPA mengintegrasikannya dengan Bahasa Indonesia, daripada mata pelajaran terpisah. Ada daftar tema pada Kemendikbud SD (2013a) tetapi tidak semua tema mempunyai konten IPA.

2). Di dalam SMP, guru-guru diharapkan mengajar mata pelajaran integrative science, yang belum ada pengalamannya.

3). Tim peneliti itu berpikir bahwa karena konten IPA dikurangi, jadi hasil peserta didik pada TIMSS atau PISA tidak diperbaiki.

4). literasi saintifik diperkenalkan sebagai potensi masalah yang lain yang akan mengganggu pembangunan Indonesia.

B. Kontroversi dan Australian Curriculum

Kurikulum 2013 bukan satu-satunya kurikulum yang menyebabkan kontroversi. Pada tahun 2014, Australian Curriculum ditinjau oleh pemerintah konservatif yang baru (Review of the Australian Curriculum, 2014). Hasilnya menyebutkan bahwa Australian Curriculum adalah kurikulum yang terlalu padat, terutama di dalam sekolah dasar. Ada konten terlalu banyak, tetapi juga kemampuan umum dan prioritas antarkurikulum.

Ada satu isu diajukan dalam laporan ini bahwa yang berhubungan pada Kurikulum 2013. Pada Australian Curriculum ada prioritas antar-kurikulum tentang Asia dan orang asli Australia, tetapi kurang memperhatikan "dampak peradaban barat dan agama Judeo-Kristen pada perkembangan dan kebiasaan Australia serta masyarakat dan budaya Australia yang lebih luas" (Review of the Australian Curriculum, 2014: 5). Itu dianggap memungkinkan peserta didik mengerti dimensi yang keagamaan dan moral kehidupan. Itu diabaikan pada Australian Curriculum tetapi termasuk dalam Kurikulum 2013 (misalnya Kompetensi Inti 1 dan 2).

\section{KESIMPULAN}

Kurikulum yang baru diperkenalkan untuk semua sekolah Indonesia pada tahun 2013. Kurikulum itu disebut Kurikulum 
2013. Kerangka yang sama digunakan pada seluruh Kurikulum 2013 untuk semua mata pelajaran untuk semua tingkat kelas. Kurikulum 2013 didasarkan dua jenjang kompetensi: Kompetensi Inti dan Kompetensi Dasar. Ada empat Kompetensi Inti untuk semua mata pelajaran dan semua tingkat kelas. Kompetensi Inti itu serupa seluruh kurikulum antar kelas. Kompetensi Inti 1 merujuk pada ajaran agama yang dianut peserta didik Indonesia. Kompetensi Inti 2 adalah kompetensi sikap sosial dan menunjukkan sikap kebudayaan Indonesia, misalnya gotong royong, terutama pada masyarakat dan keberadaan peserta didik. Kompetensi Inti 3 dan Kompetensi Inti 4 adalah tentang pengetahuan, keterampilan dan penerapan pengetahuan khusus untuk setiap mata pelajaran. Kompetensi Dasar berubah menurut mata pelajaran dan tingkat kelas. Ada banyak Kompetensi Dasar. Kompetensi Dasar dihubungkan pada dua dokumen lain, misalnya Standar Kompetensi Lulusan (SKL) dan Standar Isi (SI).

Pada Desember 2014 penerapan Kurikulum 2013 dihentikan oleh Mendikbud untuk paling banyak sekolah. Kurikulum itu diperbaiki dan sekarang digunakan oleh 25\% sekolah di Indonesia. Pengajaran IPA pada Kurikulum 2013 berubah menurut jenjang sekolah. Di SD, dalam Kelas I-III tidak ada konten IPA pada kurikulum, dan dalam Kelas IV-VI guru-guru diharapkan mengajar IPA mengintegrasikannya dengan mata pelajaran lain. Di SMP, guru-guru diharapkan agar melaksanakan pengajaran sebagai bagian dari disiplin integrative science. Di dalam SMA ada tiga mata pelajaran, misalnya Biologi, Kimia dan Fisika. Konten IPA di jenjang Sekolah Menengah Pertama pada Kurikulum 2013 dan pedagoginya adalah serupa dengan Australian Curriculum: Science di jenjang yang sama.

\section{DAFTAR PUSTAKA}

“Anies Baswedan: Pendidikan itu harus jadi kegembiraan, bukan penderitaan”. (2014). Tempo, 4342, 156-159. 15 - 21 Desember

“Kemdikbud revisi besar-besaran buku Kurikulum 2013”. (2016). Kompas.com. [Online]. Tersedia http://edukasi. kompas.com/read/2016/01/07/17291791/Kemdikbud.Revisi.Besar-besaran.Buku.Kurikulum.2013. 7 Januari

“Mulai semester genap, Kurikulum 2013 dihentikan”. (2014). Kompas.com. [Online]. Tersedia http://edukasi. kompas.com/read/2014/12/05/20042411/Mulai.Semester.Genap.Kurikulum.2013.Dihentikan. 5 Desember

ACARA. (2012). Charter for the Australian Curriculum, Assessment and Reporting Authority [Online]. Tersedia http://www.acara.edu.au/verve/_resources/ACARAs_Charter_(3_August_2012).pdf. 3 Agustus

ACARA. (2015). Australian Curriculum: Science. Version 8.1. [Online]. Tersedia http://www.australiancurriculum. edu.au/science/curriculum/f-10?layout=1

ACARA. (2016a). F-10 overview (Peninjauan luas Fondasi-Kelas X). Australian Curriculum, Assessment and Reporting Authority. [Online]. Tersedia www.australiancurriculum.edu.au/overview/structure

ACARA. (2016b). National Report on Schooling in Australia 2014 (Laporan Nasional tentang Pendidikan Sekolah di Australia 2014). [Online]. Tersedia www.acara.edu.au

Al-Samarrai, S., \& Cerdan-Infantes, P. (2012). Where did all the money go? Financing basic education in Indonesia. [Di mana semua uang? Keuangan untuk pendidikan dasar di Indonesia.] Pada D. Suryadarma \& G.W. Jones (Eds.), Education in Indonesia [Pendidikan di Indonesia] (pp.109-138). Singapore: ISEAS Publishing

Barrett, G.W. (2001). Closing the ecological cycle: The emergence of integrative science. Ecosystem Health, 7(2), $79-84$

Bjork, C. (2013). Teacher training, school norms and teacher effectiveness in Indonesia. [Pelatihan guru, norma sekolah dan keefektipan guru.] Pada D. Suryadarma \& G.W. Jones (Eds.), Education in Indonesia (pp.53-67). Singapore: ISEAS Publishing

Budiari, I. (2014, Desember 07). Anies nixes much-maligned 2013 curriculum. Jakarta Post. [Online]. Tersedia http://www.thejakartapost.com/news/2014/12/07/anies-nixes-much-maligned-2013-curriculum.html

Institute for Integrative Science and Health. (2017). Bringing together Indigenous ways of knowing and Western 
scientific knowledge. [Online]. Tersedia http://www.integrativescience.ca/

Kementerian Pendidikan dan Kebudayaan. (2012). Dokumen Kurikulum 2013. [Online]. Tersedia http://tania.fkip. uns.ac.id/wp-content/uploads/dokumen-kurikulum-2013.pdf

Kementerian Pendidikan dan Kebudayaan. (2013a). Kompetensi dasar Sekolah Dasar / Madrasah Ibtidaiyah. [Online]. Tersedia https://dl.dropboxusercontent.com/u/76277102/syadiash/syadiash_doc_down/Doc_ Kurikulum_2013/kompetensi-inti-dan-kompetensi-dasar-sd-rev9feb.pdf

Kementerian Pendidikan dan Kebudayaan. (2013b). Kompetensi dasar Sekolah Menengah Pertama / Madrasah Tsanawiyah. [On;ine]. Tersedia https://dl.dropboxusercontent.com/u/ 76277102/syadiash/syadiash_ doc_down/Doc_Kurikulum_2013/kompetensi-inti-dan-kompetensi-dasar-smp-rev9feb.pdf

Kementerian Pendidikan dan Kebudayaan. (2013c). Kompetensi dasar Sekolah Menengah Atas / Madrasah Aliyah. [Online]. Tersedia https://dl.dropboxusercontent.com/u/76277102/syadiash/syadiash_doc_down/Doc_ Kurikulum_2013/kompetensi-inti-dan-kompetensi-dasar-sma-rev9feb.pdf

Kementerian Pendidikan dan Kebudayaan. (2014). Buku Guru untuk Ilmu Pengetahuan Alam: Untuk SMP Kelas VII, edisi revisi. Jakarta: Kemendikbud

MCEETYA. (2008). Melbourne Declaration on Educational Goals for Young Australians [Deklarasi Melbourne Cita-cita Pendidikan untuk Orang Australia yang Muda]. Melbourne: Ministerial Council for Education, Employment, Training and Youth Affairs

Natahadibrata, N. (2013, Juni 26). RI kicks off 12-year compulsory education program. Jakarta Post. [Online]. Tersedia http://www.thejakartapost.com/news/2013/06/26/ri-kicks-12-year-compulsory-educationprogram.html

Nugroho, N. D. (2016, Januari 17). Jumlah sekolah pengguna kurikulum baru bertambah tahun ini. Tempo. [Online]. Tersedia https://nasional.tempo.co/read/news/2016/01/17/079737006 /jumlah-sekolahpengguna-kurikulum-baru-bertambah-tahun-ini

Nuh, M. (2013). Kurikulum 2013. Harian Kompas. 7 Maret

Peraturan Menteri Pendidikan dan Kebudayaan Republik Indonesia, Nomor 160 Tahun 2014. [Online]. Tersedia http://sulut.kemenag.go.id/file/file/undangundang/opwb1418605840.pdf

Prihantoro, C.R. (2015). The perspective of curriculum in Indonesia on environmental education [Perspektif kurikulum di Indonesia untuk pendidikan linkungan]. International Journal of Research Studies in Education, 4(1), 77-83

Ramli, M. (2014). Science educators attitudes toward the new thematic integrated curriculum in Indonesia. Edusains, 6(1), 73-86

Review of the Australian Curriculum. (2014). Final report. [Tinjauan Kurikulum Australia. Laporan terakhir]. [Online]. Tersedia http://www.studentsfirst.gov.au/strengthening-australian-curriculum

Suharti. (2013). Trends in education in Indonesia. [Kecenderungan pendidikan di Indonesia.] Pada D. Suryadarma \& G.W. Jones (Eds.), Education in Indonesia (pp.15-52). Singapore: ISEAS Publishing 